\title{
Topographic Information from Interferometric Synthetic Aperture Radar (IfSAR) for Oil Palm Plantation Design, Suitability and Management
}

\author{
Nordiana Abd Aziz ${ }^{1}$, Wahid Omar ${ }^{2}$, Mohamad Samah ${ }^{3}$ and Zulkifli Hashim ${ }^{1}$ \\ 1. Agronomy \& Geospatial Technology Unit, Biological Research Division, Malaysian Palm Oil Board (MPOB), No. 6, Persiaran \\ Institusi, Bandar Baru Bangi, Kajang 43000, Malaysia \\ 2. Integration and Extension Research Division, Malaysian Palm Oil Board (MPOB), No. 6, Persiaran Institusi, Bandar Baru Bangi, \\ Kajang 43000, Malaysia \\ 3. Seed and Plantation Management Unit, Malaysian Palm Oil Board (MPOB), No. 6, Persiaran Institusi, Bandar Baru Bangi, \\ Kajang 43000, Malaysia
}

\begin{abstract}
In this paper, authors explained on the possibility of using IfSAR (Interferometric Synthetic Aperture Radar) data to design, plan and develop new oil palm plantation. The study was carried out in MPOB (Malaysian Palm Oil Board) research station located in Jerantut, Pahang. The importance of the study was to demonstrate the process of using IfSAR data using geospatial technology to visualize the land assessment for better plantation planning and future management. Development of plantation database such as block mapping, palm trees, soil type, roads and drainage length, topography etc. will give alternative uses to decision makers and land owners. Integration of these technologies and the availability of more spatial data will make planning, developing and monitoring of the current and future plantation activities become easier. Under the present stringent requirement with respect to the environment, these technologies could assist the plantation in meeting the certification standards.
\end{abstract}

Key words: IfSAR, digital terrain elevation data, oil palm plantation.

\section{Introduction}

The geospatial technology consisting of GPS (Global Positioning System), RS (Remote Sensing) and GIS (Geographic Information systems) has been extensively used in enhancing mapping capability. GIS is computer software and hardware systems that enable users to capture, store, analyze and manage spatially referenced data. GIS has transformed the way spatial data, relationships and patterns in the world are able to be interactively queried, processed, analyzed, mapped, modelled, visualised and displayed for an increasingly large range of users, for a multitude of purposes. Geospatial data in the form of remotely sensed imagery and other raster formats have been

Corresponding author: Nordiana Abd Aziz, master, main research field: geospatial technology, oil palm agronomy. collected at increasing extent and finer resolution. Spatial data is transformed and processed to understand its relationships and patterns. Geospatial databases with the combination of various types of remote sensing images are becoming gradually important to obtain overview of the area for designing and planning work of oil palm plantation. It also helps easy visualisation for more meaningful interpretation. Abdullah, et al. [1] reported that mobile data can be used to acquire the location of the oil palm trees and Interferometric synthetic aperture radar (IfSaR) data was used to map the extent of the oil palm plantation. Adzemi et al used GIS to determine the suitability classes of the land based on the best characteristics for cultivating the oil palm [2].

IFSAR is one of the remote sensing image available for elevation data and corresponding orthorectified 
radar images of the earth's surface [3]. Adoption of improved and detailed elevation data from time to time will provide better interpretations and produced significant accuracy of the mapping output. Proper planning at the initial stage will improve the performance of the yield commodity. In Malaysia, among commodity sector, oil palm contributes major economic impact after oil and gas sector. In 2018, it was reported about 5,849,330 ha has been planted in Malaysia [4]. Proper land evaluation will improved the management practices and thus increase the oil palm yield.

Nordiana, et al. [5] used the application of geospatial technology to evaluate an undulating land for oil palm cultivation. Land evaluation was carried out to characterize the slope pattern using Synthetic Aperture Radar (SAR), investigate the suitable plantation block for plantable and unplantable and determine the planting palm point.

IfSAR is a new source of SAR (Synthetic Aperture Radar) data to derive accurate, economic and efficient topographic information or Digital Elevation Model (DEM) without any effect of cloud cover for intensive mapping. The technology exploits the coherent nature of SAR echoes (i.e., the signals are recorded in both amplitude and phase) to measure difference in the phase from each patch of the surface when observed from slightly different locations and/or times. These phase differences can be attributed to differences in path length between the two signals. The path-length differences are a function of: (1) the distance and angles of the radar antennas making the observations, (2) the topography of the surface, (3) a change in the position of patches of the surface, and (4) differences in atmospheric or ionospheric conditions along the two paths. If the two observations are made simultaneously from a pair of radar antennas on a single platform, item (1) above is well known and the effects of items (3) and (4) are negligible, leaving item (2), the surface topography, as the controlling factor [6].
IfSAR used pairs of high resolution SAR images to generate high quality terrain elevation maps, called DEMs, using phase interferometry methods. The high spatial resolution of SAR imagery enables independent measurements of terrain elevation on a dense grid of sample points, while the use of phase-based measurements at microwave frequencies attains height accuracies of one meter. Furthermore, the use of active microwave radar as the sensor inherently provides an all-weather, day/night capability to generate DEMs. Variations on the IfSAR concept can also provide high quality measurements of changes in the terrain profile over time, or of changes in the reflectivity of the terrain [7].

This study involved the utilisation of IfSAR (Interferometric Synthetic Aperture Radar) as a source of RS data and the application of GPS and GIS to design, plan and develop new oil palm plantation. DEM is a numerical description of the earth's topography or surface. It is a fundamental layer of a geospatial infrastructure framework and necessary for many geospatial applications. Studies have demonstrated the potential of the interferometric technique to produce high-resolution DEM with relative height errors of $5 \mathrm{~m}$ or less, tests with 3-day repeat-pass by the first ERS-1 (European RS Satellite) imagery [8].

\section{Material and Methods}

This study was conducted in Jerantut, which is situated in the subdistrict of Tembeling, Pahang at geographic location (upper left: $102^{\circ} 23^{\prime} 34.512^{\prime \prime} \mathrm{E}$, $4^{\circ} 18^{\prime} 6.175^{\prime \prime} \mathrm{N}$, and lower right: $102^{\circ} 25^{\prime} 16.84^{\prime \prime} \mathrm{E}$, $\left.4^{\circ} 16^{\prime} 47.763^{\prime \prime} \mathrm{N}\right)$. The total area of the study is 339.04 ha. At present, the area is surrounded with secondary forest. However, the adjacent area has been planted with oil palm, i.e Ladang Felcra Tembeling which is located at the northern part of the area. This is supported by the land use type shown in the WorldView-1 satellite image acquired on 18th January 2012 (Fig. 1). Part of the area is hilly where the highest recorded altitude is $333 \mathrm{~m}$ above sea level. 


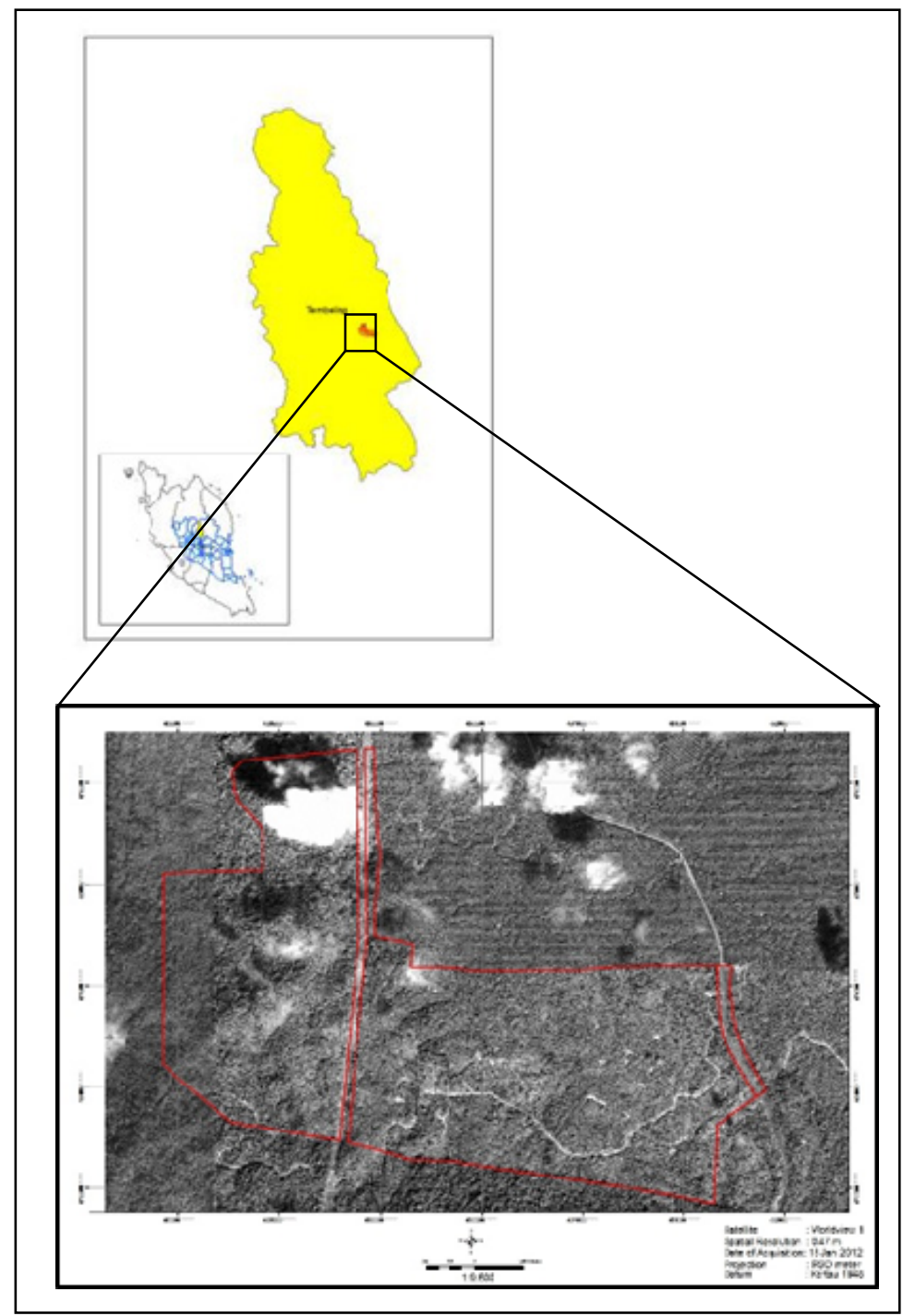

Fig. 1 Study area at Jerantut, Pahang.

\section{Satellite Image}

IfSAR is a promising technology for its competitive cost effective Three Dimensional (3D) mapping especially for wide area coverage. This technology offers 3 core products which consist of Digital Surface Model (DSM), Digital Terrain Model (DTM) and Orthorectified Radar Imagery (ORI). The systems collect raw radar data based on a pre-determined mission plan. Height information for a scene is obtained from an IfSAR system by using the relative phase difference between two coherent SAR images simultaneously obtained by two antennas separated by an across-track baseline in a single-pass mode (Fig. 2).
In this study, IfSAR Type I data were used. DSM and DTM data were provided in Band Interleaved by Line (BIL) format while ORI in Geo Tagged Image File Format (GeoTIFF). The pixel size of ORI was $0.625 \mathrm{~m}$ and it was resourceful for evaluating land cover and surface mapping. Table 1 lists the major parameters of these products.

\subsection{DSM (Digital Surface Model)}

As DSM is corresponding to the initial reflective surface illuminated by the radar, the unobstructed areas of moderately sloped topography will influence the accuracy. Extreme terrain condition and 


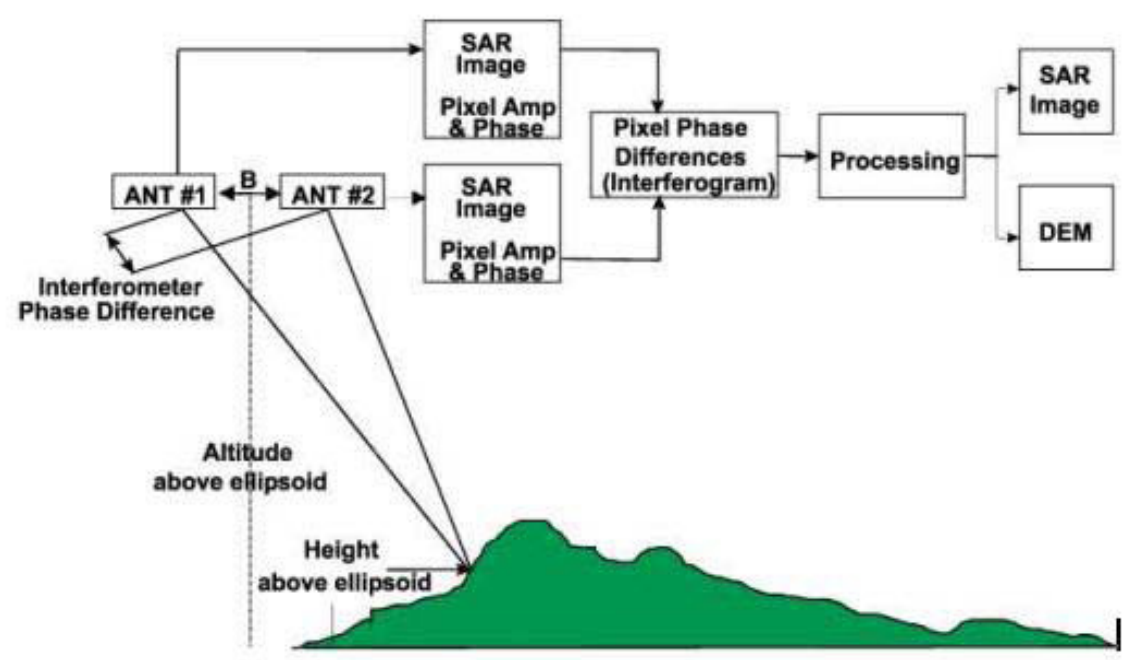

Fig. 2 Concept of IfSAR mapping.

Table 1 IfSAR Image characteristics.

\begin{tabular}{lll}
\hline $\begin{array}{l}\text { IfSAR } \\
\text { product }\end{array}$ & Post spacing (m) & $\begin{array}{l}\text { RMSE (Root Mean Square } \\
\text { Error) accuracy }\end{array}$ \\
\hline DSM & $\begin{array}{l}5.0 \\
\text { (nominal) }\end{array}$ & $\begin{array}{l}\text { Type I: } 0.5 \mathrm{~m} \\
\text { Type II: } 1.0 \mathrm{~m} \\
\text { Type III: } 3.0 \mathrm{~m}\end{array}$ \\
DTM & $\begin{array}{l}5.0 \\
\text { (nominal) }\end{array}$ & $\begin{array}{l}\text { Type I: } 0.7 \mathrm{~m} \\
\text { Type II: } 1.0 \mathrm{~m}\end{array}$ \\
ORI & $\begin{array}{l}1.25 \text { or } 2.5 \\
\text { (nominal) }\end{array}$ & Types I, II \& III: $2.0 \mathrm{~m}$ \\
\hline
\end{tabular}

dense vegetation will lessen the data accuracies. It is used primarily for 3D visualisation, geospatial analysis and line-of-sight applications. More applications related to forest analysis such as biomass studies are suitable with the combination of DSM and DTM data.

\subsection{DTM (Digital Terrain Model)}

Depiction of the bare earth for every single 5 metres is identified by the DTM information which was originated from the DSM using exclusive formula and also modified procedures. Severe surface problem as well as dense vegetation will certainly decrease the information reliabilities. It was utilized in lots of applications consisting of contours as well as 3D mapping, flooding preparation as well as numerous essential information layers in geospatial mapping.

\subsection{ORI}

ORI is a raster-based image representing terrain information caused by the radar initial response signal and it coincide spatially with DSM and DTM. It remained as contiguous dataset of captured area. It is useful for visual representation and various applications such as feature classification and spatial reference with aerial and other satellite images. The accuracy of represented ORI data may differ due to radar shadow and layover in high-relied areas for example mountainous, dense vegetation and highly developed urban areas where the look direction of the radar system occurred. Figs. 3a-3b illustrated the DSM, DTM and ORI product data respectively.

\subsection{Topographic Map}

Topographic map of Kuala Tembeling area with sheet No. 4061 of L7030 series was used as reference. The referral scale was 1:50,000. Other supporting data used were the site survey map of the proposed Jerantut station. The surveyed map was scanned and digitised into ArcGIS software for further processing.

\subsection{Equipment and Software}

\subsubsection{Geo-XH}

Trimble Geo-XH was used for ground truthing, checking and tracking of the boundary area. Points collected from the device were corrected using post differential method. As the accuracy of the measurement device can reach up to centimetres, it was then used to 


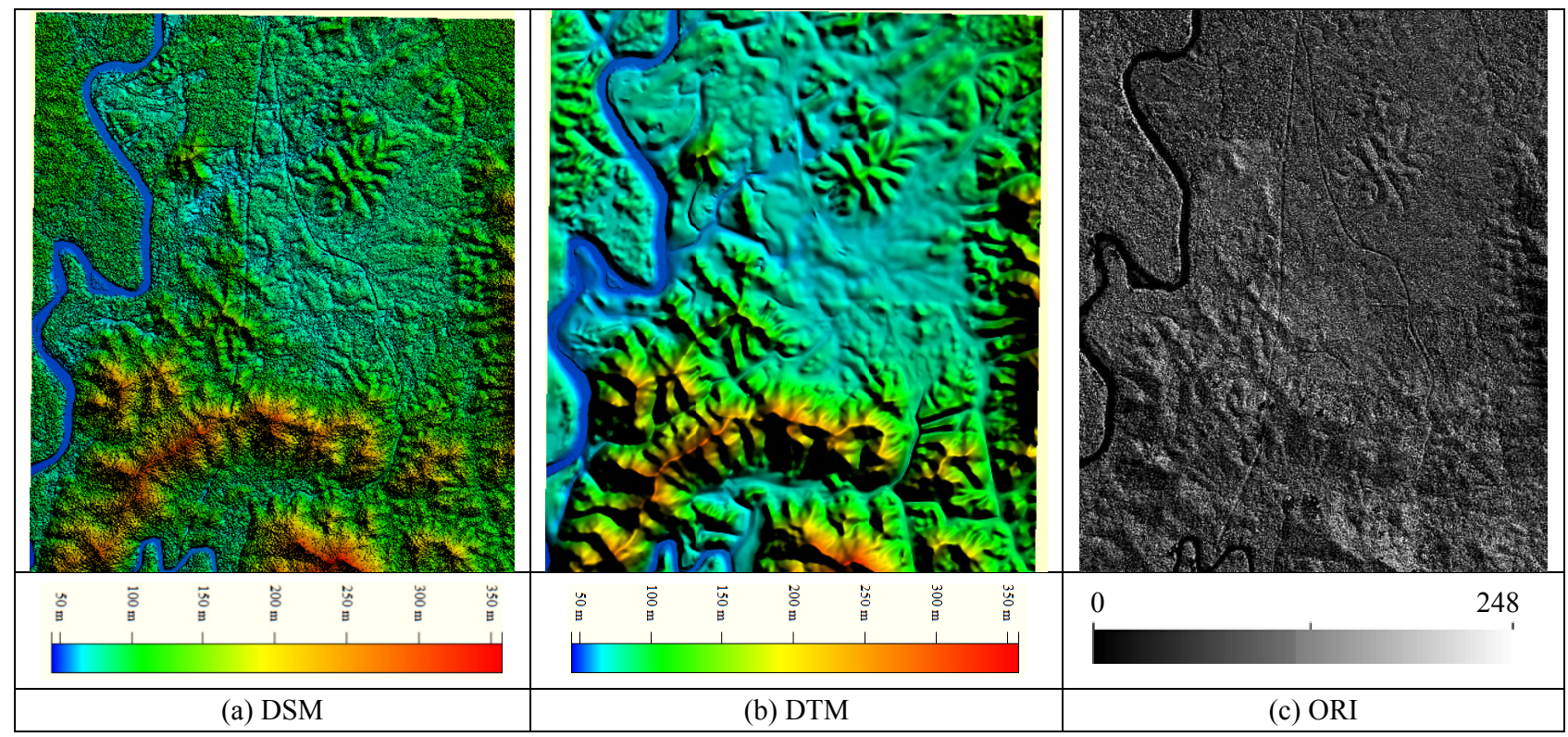

Fig. 3 IfSAR data product for respective study area.

check the accuracy and reliability of the generated contour lines, terracing and palm planting point of the study area. The Global Mapper was used to process and analyse the satellite images.

\subsection{Satellite Image Pre-processing}

\subsubsection{IfSAR Data Pre-processing}

Data were initially pre-processed at on-board aircraft by the image provider. As the aircraft passes over the terrain, GPS data from both aircraft and ground-based GPS devices as well as navigation data from an Inertial Measurement Unit (IMU) onboard the aircraft were collected. Those navigation data were then processed to provide the precise position of the aircraft. The phase difference between the antenna for each image point - along with range, baseline, GPS and navigation data - was used to infer the precise topographic height of the terrain being imaged. This step was performed to create an interferogram (depicting the phase difference) in order to produce DSM.

\subsubsection{Data Conversion}

Pre-processing involves data conversion of different formats and georeferencing of those data to reduce the ambiguity of raster data. Raw satellite image in BIL was converted to GeoTIFF.

\subsubsection{Co-registration}

For further processing, the initial IfSAR image which was in original projection of World Geodetic System (WGS) in 1984 was converted into local projection of Peninsular Malaysia, Rectified Skew Orthomorphic (RSO). It was necessary to ensure proper alignment of those data in any related processing software for further GIS thematic analysis.

\subsection{Contour and 3D Analysis}

The contour lines were generated from DTM data in raster format. DTM was a digital representation of ground surface topography and also commonly known as DEM. DTM is the basis of preliminary investigation survey and visual interpretation of land topography. Fig. 4 demonstrates the $1 \mathrm{~m}$ contour interval that was extracted from the DTM (Fig. 5). The 3D analyst tool in the ArcGIS was used to analyze the topography, slope and orientation land surface of the study area.

\subsection{Subset of Contour Lines}

The contour lines were subset/cropped into specific study area. The process reduced size and improved time of processing and analyzing of the contour lines. 


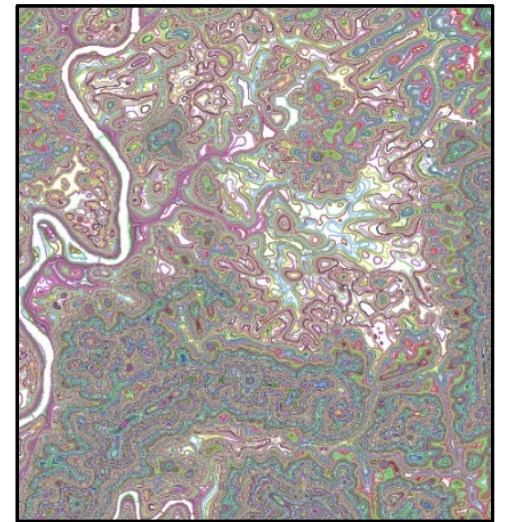

Fig. 4 Contour lines derived from DTM IfSAR.

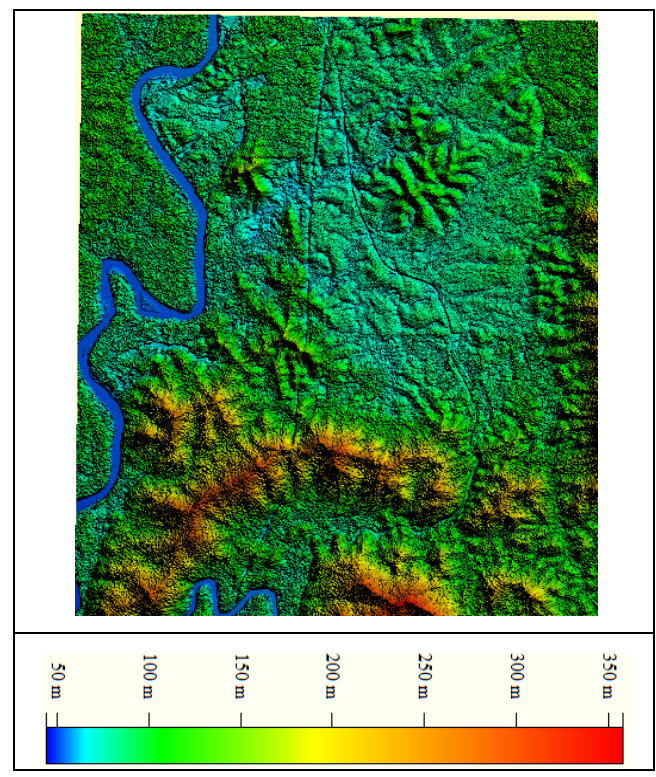

Fig. 5 DTM from IfSAR.

\subsection{Creating Slope and Terrace Lines}

\subsubsection{Creating Slope Map}

Based on derived contour lines from DTM data, plantation parameters such as slope, terrace lines and others were created and designed. Table 2 illustrated the categories of slope and terrace requirement.

\subsubsection{Creating Terrace Line}

Terracing is recommended for oil palm cultivation on land with a slope more than $7^{\circ}$. The standard specification of horizontal distance between terraces for oil palm cultivation is $9 \mathrm{~m}$. The vertical distance between terraces is dependent on the degree of the slope and it is higher for the steeper slope compared to the gentler one. Fig. 6 shows the schematic diagram of terraces in relation to degree of the slope.

For slopes category $7-15^{\circ}, 11^{\circ}$ was considered as a mean of this slope category. The vertical distances (A) of the terraces in this slope category were determined by computing the $11^{\circ}$ in the formula which indicated the distance was $1.7 \mathrm{~m}$. This value was then used to create the computerized terrace lines for the entire study area. For the slope category $16-24^{\circ}, 20^{\circ}$ was the mean and computation of the mean indicated that the vertical distance between the terraces was $3.4 \mathrm{~m}$. The terrace lines and this value were derived by skipping one terrace line of the $7-15^{\circ}$ slope category. The terrace lines were created based on contour lines interval at $1.0 \mathrm{~m}$. The terrace line map was overlaid on the slope map to edit the terrace lines for slope $7-15^{\circ}$ and $16-24^{\circ}$.

\subsection{Main road Alignment, Field Road and Drain}

There must be sufficient road networks in order to have good FFB evacuation systems. The main roads were considered as the block boundaries for the plantation in this study. The roads were created in straight line for every 20 planting lines on flat land. For hilly areas, the road alignment cut across the terraces from the lower ground up to the hill top at $8-10^{\circ}$ climbing slope. Sufficient drain networks are important for low lying areas to avoid flooding. General recommendation for drain intensity is one drain for every four to eight oil palm planting lines depending on elevation and water table levels of the area.

\subsection{Flow Chart of the Study}

All design works were based on 3D model for better visualization. Fig. 7 shows the flow chart of overall activities carried out in this study for land evaluation and development for oil palm cultivation.

Table 2 Categories of slope $\&$ terrace requirement.

\begin{tabular}{lll}
\hline Slope & Categories & Terracing \\
\hline $0-6^{\circ}$ & Flat & No \\
$7-15^{\circ}$ & Rolling to undulating & Yes \\
$16-24^{\circ}$ & Hilly & Yes \\
$>25^{\circ}$ & Steep & Yes \\
\hline
\end{tabular}




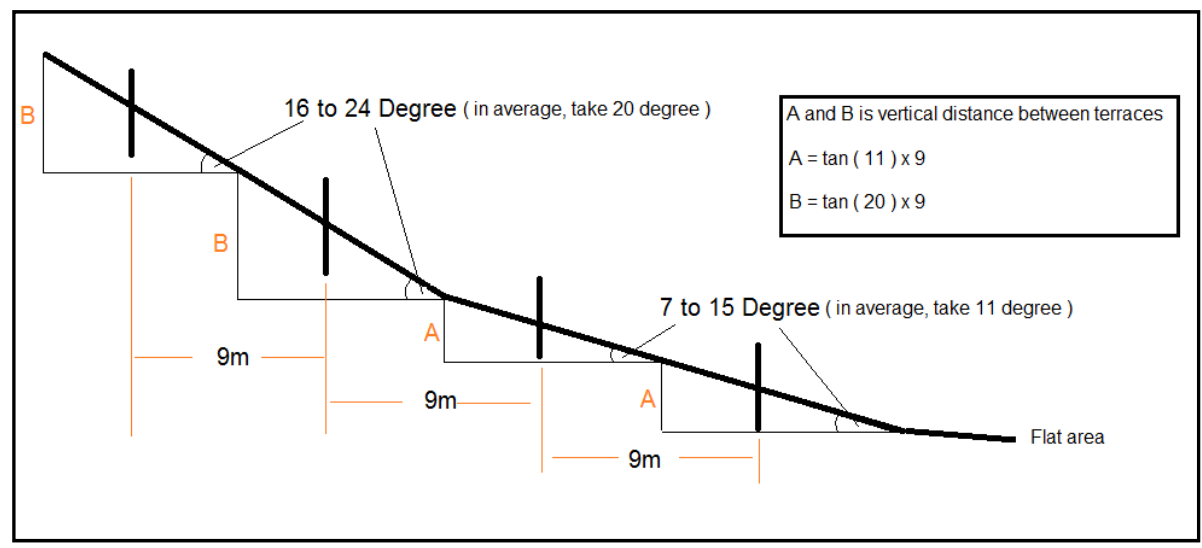

Fig. 6 Schematic diagram of oil palm terraces in relation to degree of the slope.

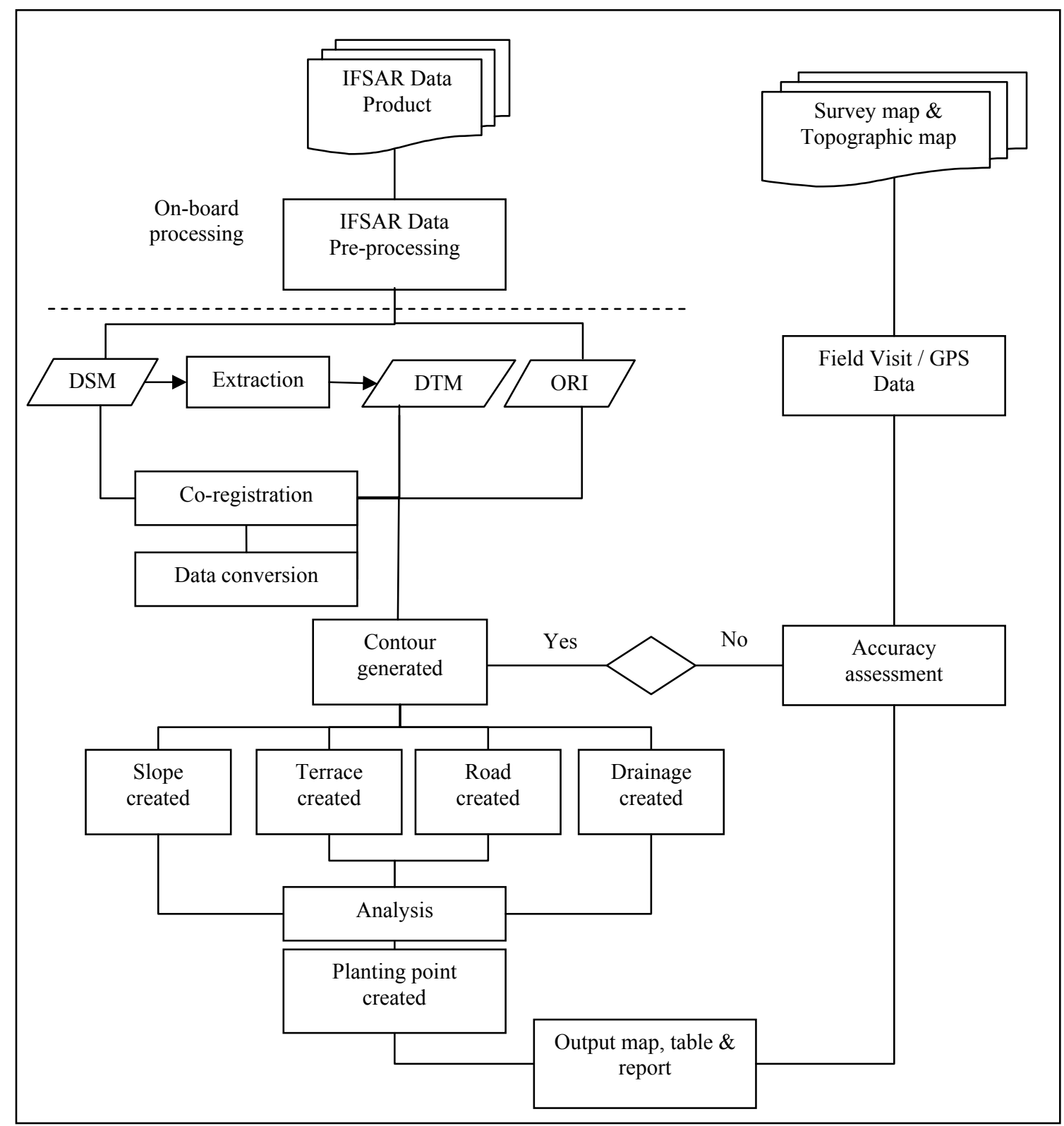

Fig. 7 Flow chart of land evaluation and development for oil palm cultivation. 


\section{Results and Discussion}

\subsection{Land Assessment}

Total area of land approved to be developed as Jerantut station was 339.04 ha (Table 3). However, after terrain assessment was carried out, 60.6 ha of the area was classified as unplantable area. This included road, drain, perimeter buffer, steep slope $(>25$ degrees), quarters and office. Thus, remaining planted area was 278.44 ha or $82.13 \%$.

\subsection{Block Analysis}

After allocating of about 5.75 ha for nursery area, the total area was divided into 5 blocks (Block A, B, C, $\mathrm{D}$ and $\mathrm{E}$ ). In each block, it was divided again into 2 sub-blocks, for instance sub-blocks A1 and A2 for block A (Fig. 8). Detailed analysis of non-agriculture area for each sub-block was given in Table 4.

\section{Table 3 Overall land information.}

\begin{tabular}{lll}
\hline Land & Area (ha) & Percentage (\%) \\
\hline (A) Plantable area & 278.44 & 82.13 \\
(B) Non-agriculture area & & \\
Road (main road and agriculture road) & 22.18 & 6.54 \\
Drain (main drain, collection drain and field drain) & 3.13 & 0.92 \\
Perimeter buffer (drain, road, electric fence) & 9.17 & 2.70 \\
Non-plantable terrain (> 25 degrees) & 15.82 & 4.67 \\
Quarters and office & 10.30 & 3.04 \\
Sub total & 60.60 & 17.87 \\
Total land area & 339.04 & 100.00 \\
\hline
\end{tabular}

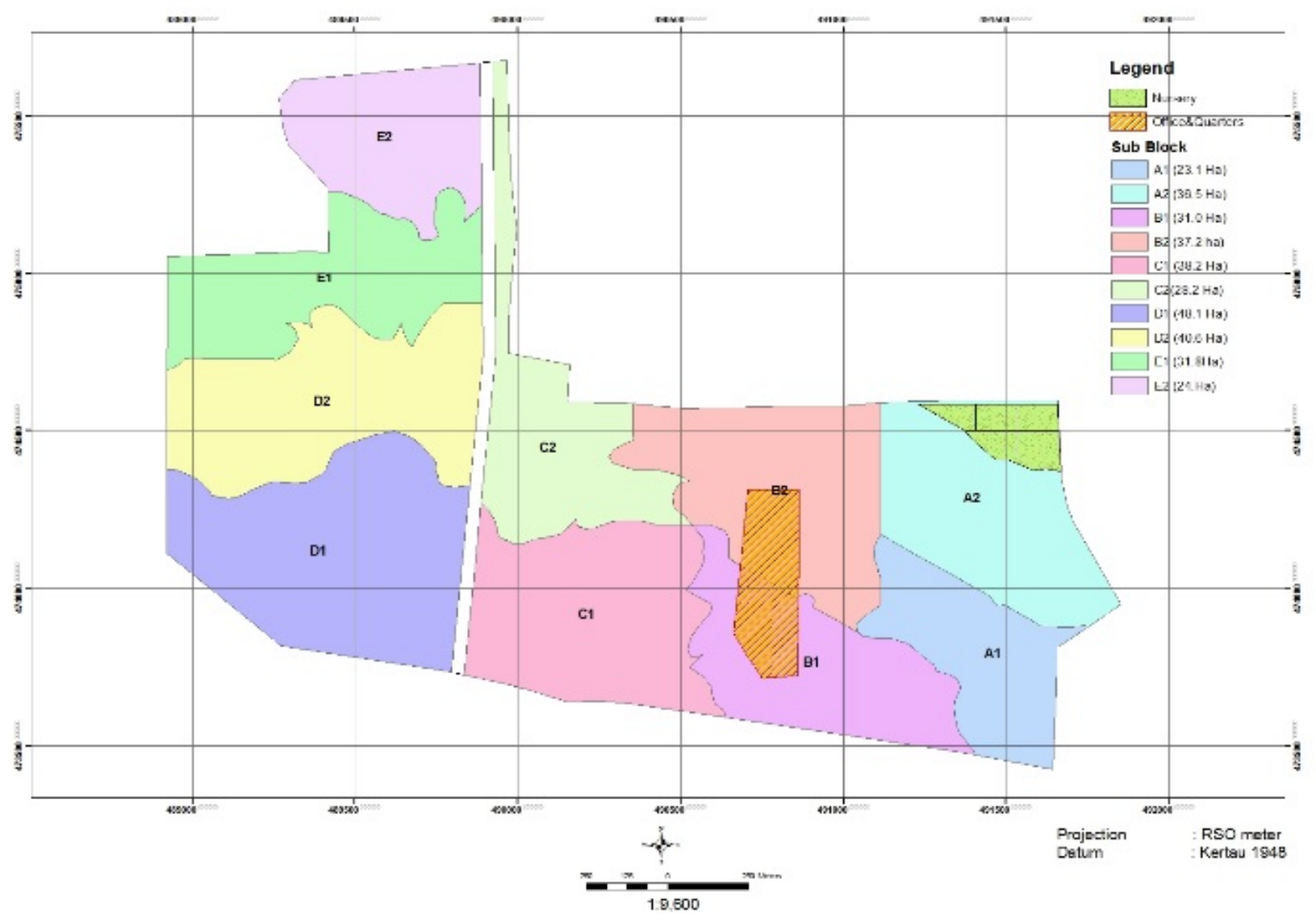

Fig. 8 Blocks. 


\section{Design, Suitability and Management}

Table 4 Detailed block analysis.

\begin{tabular}{|c|c|c|c|c|c|c|c|c|c|}
\hline \multirow[b]{2}{*}{ Block* } & \multirow{2}{*}{$\begin{array}{l}\text { Total } \\
\text { area } \\
\text { (ha) }\end{array}$} & \multirow[b]{2}{*}{ Sub-block } & \multirow{2}{*}{$\begin{array}{l}\text { Total } \\
\text { area (ha) }\end{array}$} & \multicolumn{5}{|c|}{ Unplantable area (ha) } & \multirow{2}{*}{$\begin{array}{l}\text { Plantable area } \\
\text { (ha) }\end{array}$} \\
\hline & & & & $\begin{array}{l}\text { Slope }> \\
25 \text { degrees }\end{array}$ & Road** & $\begin{array}{l}\text { Perimeter } \\
\text { buffer*** }\end{array}$ & Drainage & $\begin{array}{l}\text { Office and } \\
\text { drainage }\end{array}$ & \\
\hline \multirow{2}{*}{ A } & \multirow{2}{*}{58.96} & A1 & 23.12 & 0.00 & 1.52 & 0.74 & 0.26 & 0.00 & 20.61 \\
\hline & & A2 & 36.48 & 0.00 & 1.61 & 1.10 & 1.25 & 0.00 & 32.52 \\
\hline \multirow{2}{*}{ B } & \multirow{2}{*}{67.42} & B1 & 31.02 & 0.00 & 1.65 & 0.77 & 0.46 & 5.32 & 22.81 \\
\hline & & B2 & 37.25 & 0.00 & 2.15 & 0.76 & 0.99 & 4.98 & 28.38 \\
\hline \multirow[t]{2}{*}{$\mathrm{C}$} & \multirow[t]{2}{*}{67.94} & $\mathrm{C} 1$ & 38.25 & 0.00 & 2.96 & 0.82 & 0.18 & 0.00 & 34.30 \\
\hline & & $\mathrm{C} 2$ & 28.20 & 1.03 & 2.19 & 1.39 & 0.00 & 0.00 & 23.59 \\
\hline \multirow{2}{*}{ D } & \multirow{2}{*}{88.61} & D1 & 48.04 & 5.54 & 3.47 & 1.24 & 0.00 & 0.00 & 37.79 \\
\hline & & D2 & 40.57 & 9.26 & 2.38 & 0.32 & 0.00 & 0.00 & 28.61 \\
\hline \multirow{3}{*}{$\mathrm{E}$} & \multirow{2}{*}{56.11} & E1 & 31.81 & 0.00 & 2.44 & 1.04 & 0.00 & 0.00 & 28.33 \\
\hline & & E2 & 24.29 & 0.00 & 1.80 & 0.98 & 0.00 & 0.00 & 21.51 \\
\hline & 339.04 & & 339.04 & 15.82 & 22.18 & 9.17 & 3.13 & 10.30 & 278.44 \\
\hline
\end{tabular}

* TNB trail was not included;

** Two types road was considered: main road and agriculture road;

*** Included perimeter drain, perimeter road and electric fence.

\subsection{Road Network Analysis}

\subsection{Slope and Terrain Analysis}

In this study, two types of road known as main road and agriculture road were designed where the total length of the road including the perimeter boundary road was 56,022.13 m (Table 5). Density of road was $165.06 \mathrm{~m} / \mathrm{ha}$. Detailed road analysis in each block was given in Table 6 and Fig. 9.

Based on elevation data as derived from contour lines (Fig. 10), the slope and terrain analysis were performed. The range of the elevation started from $54 \mathrm{~m}$ to $180 \mathrm{~m}$ from MSL (Mean Sea Level). Four classes of slope were generated as in Table 7 and Fig. 11.

Table 5 Road network.

\begin{tabular}{ll}
\hline Type & Length $(\mathrm{m})$ \\
\hline Main road & $8,072.66$ \\
Agricultural road & $39,891.31$ \\
Perimeter boundary road & $8,058.16$ \\
Total & $56,022.13$ \\
\hline
\end{tabular}

Table 6 Detailed road analysis in each block.

\begin{tabular}{llllll}
\hline \multirow{2}{*}{ Block } & \multirow{2}{*}{ Sub-block } & Area (ha) & \multicolumn{3}{c}{ Road types } \\
\cline { 5 - 6 } & & & Main road (ha) & Agricultural road (ha) & Perimeter boundary road (ha) \\
\hline \multirow{2}{*}{ A } & A1 & 23.12 & 0.12 & 1.39 & 0.33 \\
& A2 & 36.48 & 0.53 & 1.08 & 0.35 \\
B & B1 & 31.02 & 0.25 & 1.34 & 0.35 \\
& B2 & 37.25 & 0.90 & 1.08 & 0.34 \\
C & C1 & 38.25 & 0.90 & 2.25 & 0.37 \\
& C2 & 28.20 & 0.70 & 1.51 & 0.57 \\
D & D1 & 48.04 & 0.91 & 2.63 & 0.56 \\
& D2 & 40.57 & 0.57 & 1.82 & 0.14 \\
E & E1 & 31.81 & 0.32 & 2.04 & 0.47 \\
Total & E2 & 24.29 & 0.37 & 1.44 & 0.44 \\
\hline
\end{tabular}



Design, Suitability and Management

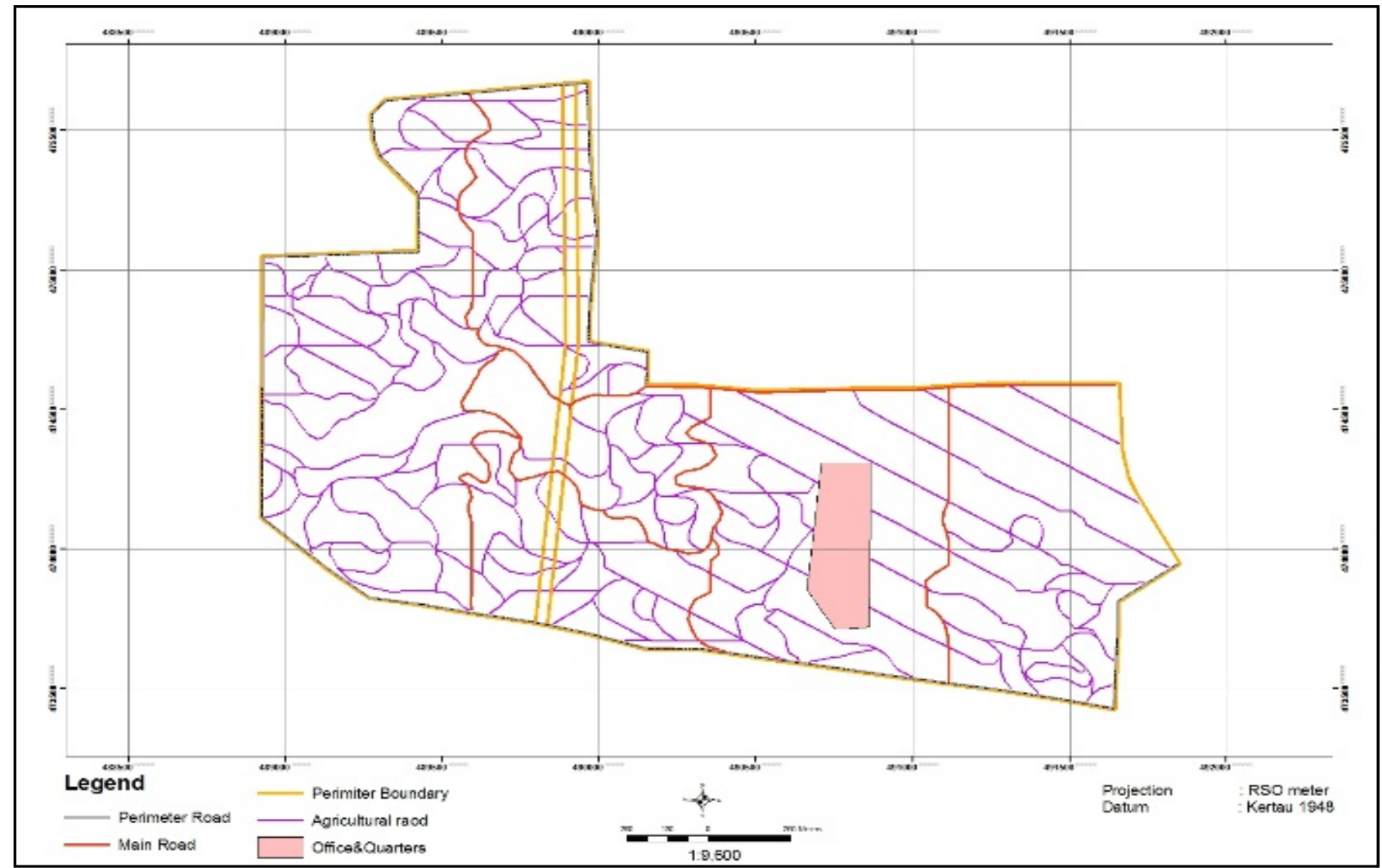

Fig. 9 Road network.

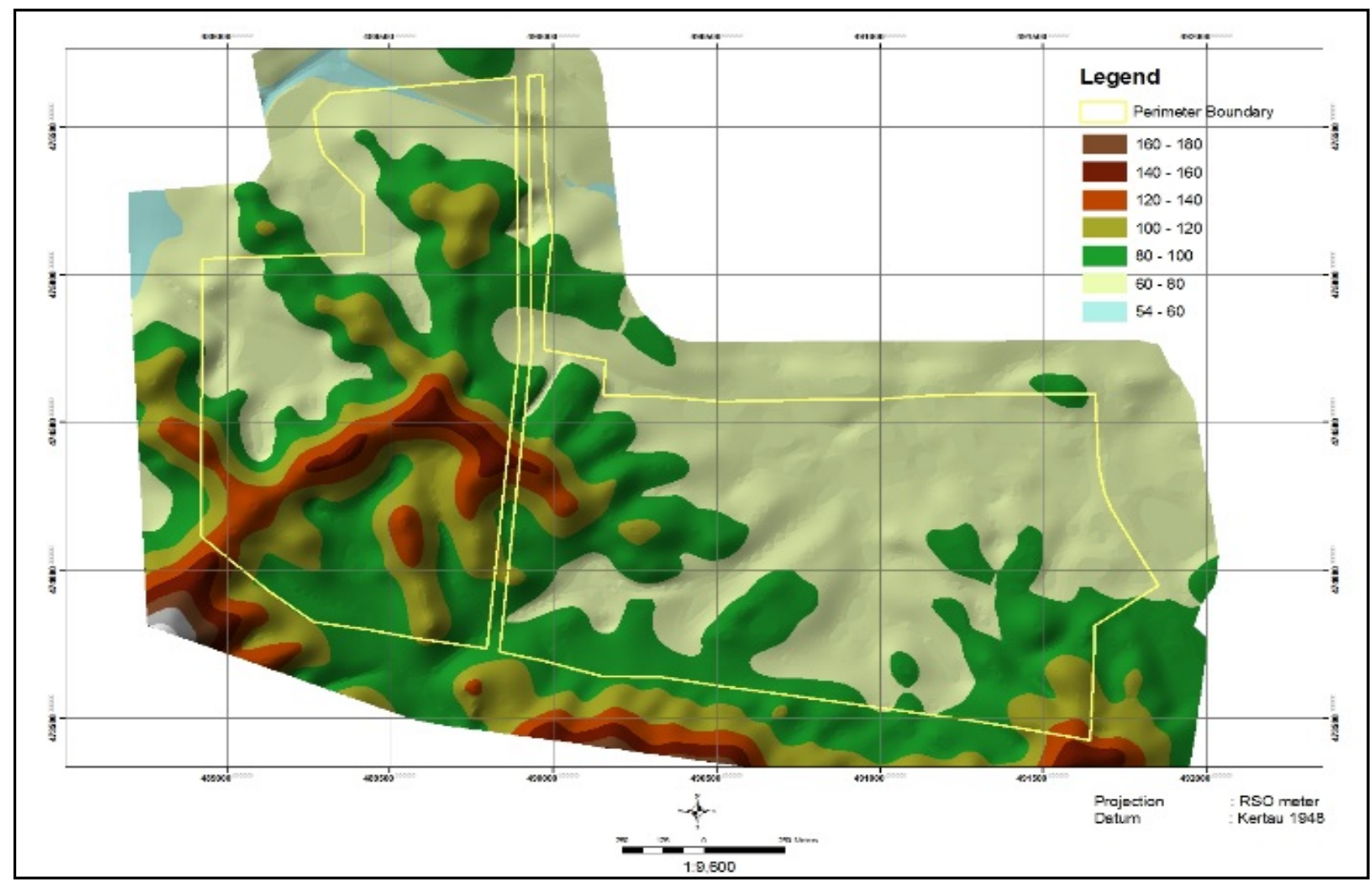

Fig. 10 Elevation. 


\section{Design, Suitability and Management}

Table 7 Slope analysis.

\begin{tabular}{lll}
\hline Slope class (degree) & Total area (ha) & Percentage (\%) \\
\hline $0-6$ & 98.09 & 28.92 \\
$7-15$ & 160.0 & 47.18 \\
$16-24$ & 64.54 & 19.03 \\
$>25$ & 16.48 & 4.86 \\
Total & 339.11 & 100 \\
\hline
\end{tabular}

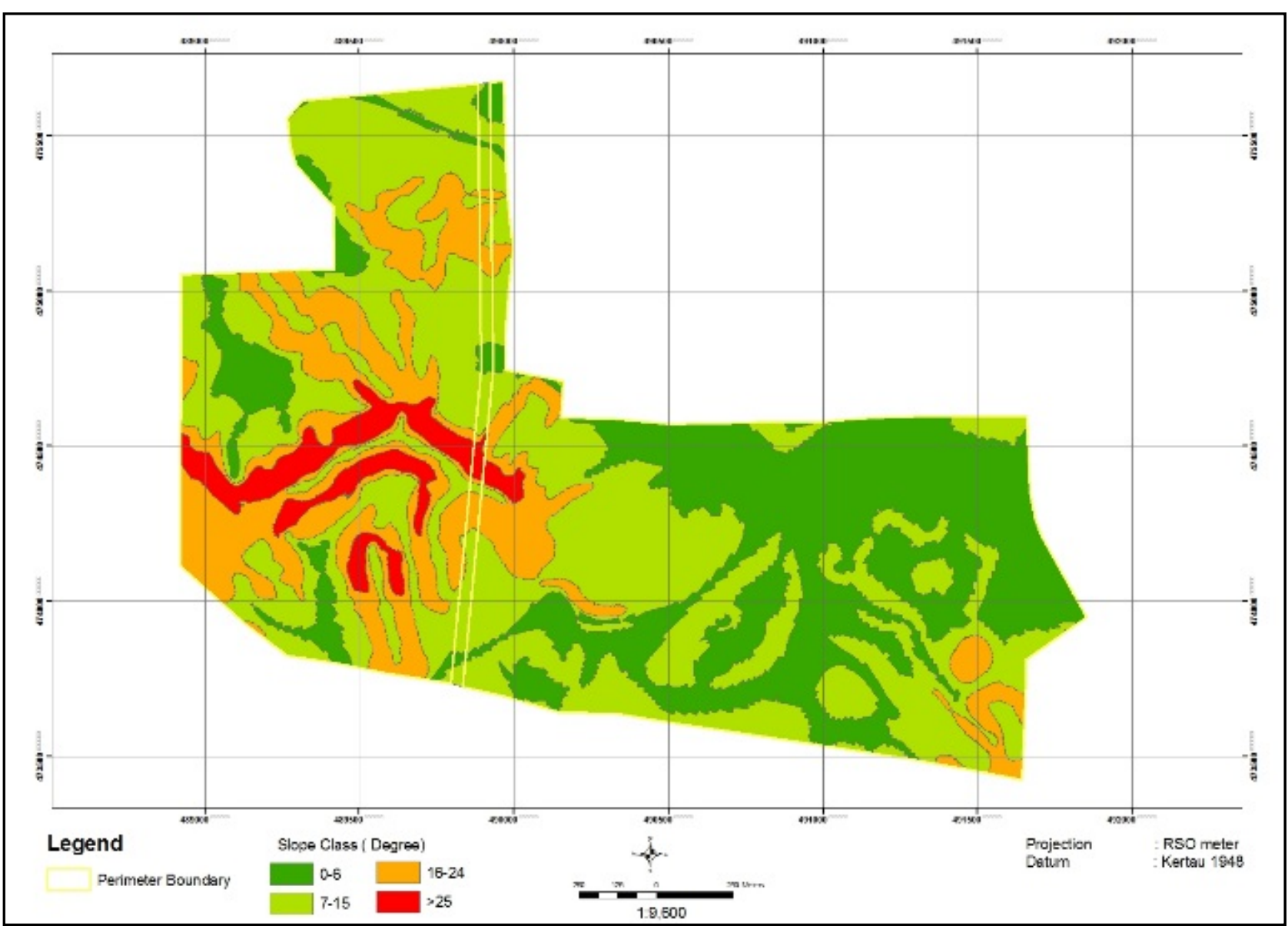

Fig. 11 Slope map.

\subsection{Terrace Design}

In this study, two forms of terraces were determined (Table 8 and Fig. 12). The single terrace and double terrace lining were built at the slope of $16^{\circ}$ to $24^{\circ}$ and $7^{\circ}$ to $15^{\circ}$, respectively. Length of the terrace was $195.1 \mathrm{~km}$ and the density was $575.2 \mathrm{~m} / \mathrm{ha}$. Tables 9 and 10 show the detailed justification of each form of terrace.

\subsection{Estimation of Palm Planting Point}

Total estimated palm planting point was initially defined based on the slope class. From the analysis, total planting point was 36,432 which was divided into $14,329\left(0-6^{\circ}\right), 14,930\left(7-15^{\circ}\right)$ and 7,173 (16-24 $)$. Statistical data of the overall palm in each slope and palm per block analysis are shown in Tables 11 and 12. The distribution of the planting point is indicated in Fig. 13.

Table 8 Terrace.

\begin{tabular}{ll}
\hline Terrace form & Length $(\mathrm{km})$ \\
\hline Single & 64.1 \\
Double & 131.0 \\
Total & 195.1 \\
\hline
\end{tabular}




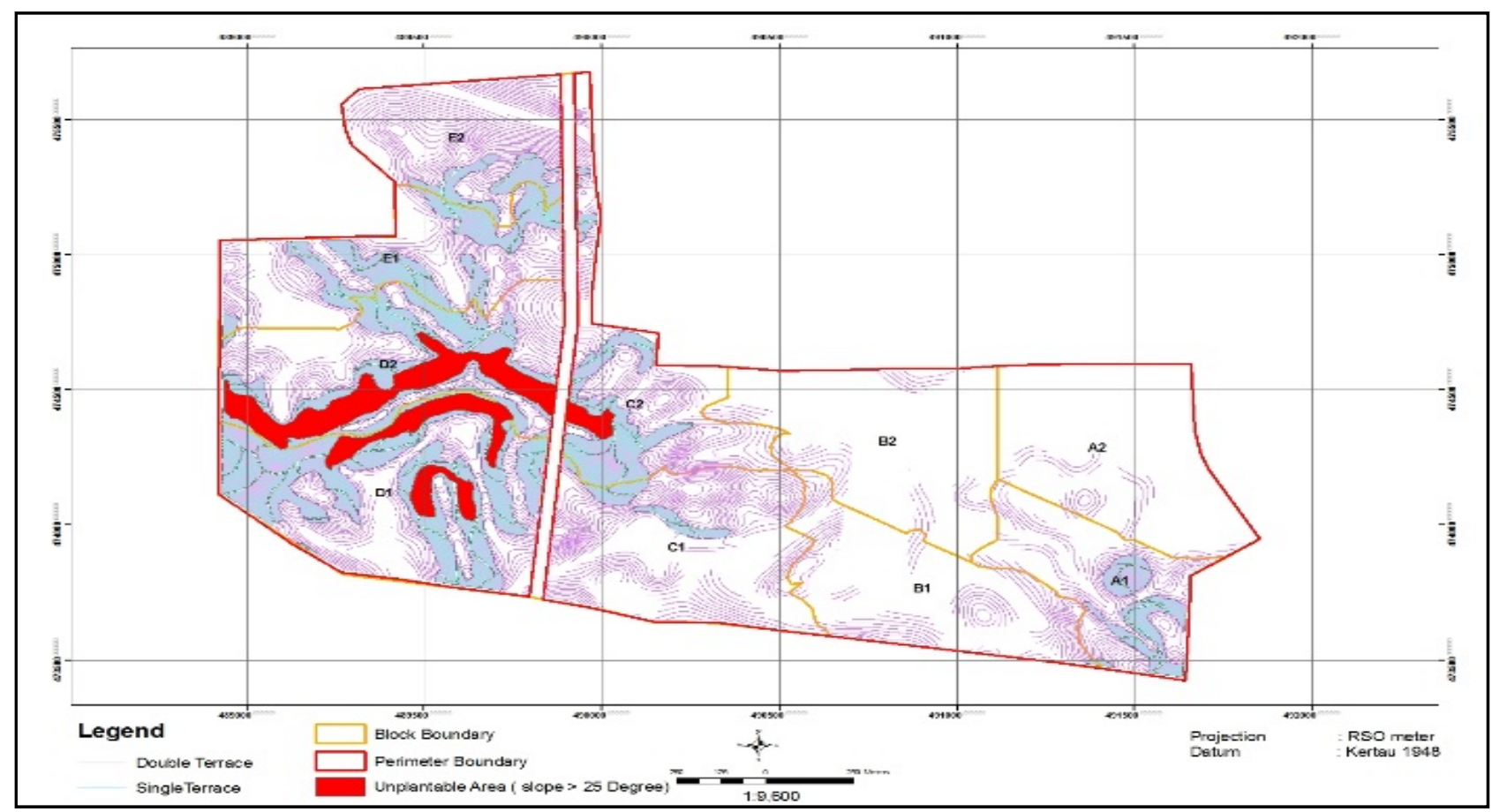

Fig. 12 Terrace map.

Table 9 Single terrace.

\begin{tabular}{lllll}
\hline Block & Sub-block & Total area $(\mathrm{ha})$ & Terrace length $(\mathrm{m})$ & Density $(\mathrm{m} / \mathrm{ha})$ \\
\hline A & A1 & 23.12 & $4,321.21$ & 186.91 \\
& A2 & 36.48 & 0.00 & 0.00 \\
B & B1 & 31.02 & 40.91 & 1.32 \\
& B2 & 37.25 & 0.00 & 0.00 \\
C & C1 & 38.25 & $2,367.79$ & 61.90 \\
& C2 & 28.20 & $8,110.40$ & 287.65 \\
D & D1 & 48.04 & $22,395.78$ & 466.18 \\
& D2 & 40.57 & $12,805.20$ & 315.60 \\
E & E1 & 31.81 & $10,697.25$ & 336.24 \\
Total & E2 & 24.29 & $3,348.09$ & 137.82 \\
\hline
\end{tabular}

Table 10 Double terrace.

\begin{tabular}{lllll}
\hline Block & Sub-block & $\begin{array}{l}\text { Total area } \\
(\text { ha) }\end{array}$ & Terrace length $(\mathrm{m})$ & Density (m/ha) \\
\hline A & A1 & 23.12 & $10,825.38$ & 468.24 \\
& A2 & 36.48 & $2,764.32$ & 75.79 \\
B & B1 & 31.02 & $10,831.18$ & 349.14 \\
& B2 & 37.25 & $4,239.81$ & 113.81 \\
C & C1 & 38.25 & $23,320.45$ & 609.68 \\
& C2 & 28.20 & $14,835.44$ & 526.16 \\
D & D1 & 48.04 & $16,309.69$ & 339.49 \\
& D2 & 40.57 & $14,944.22$ & 368.32 \\
E & E1 & 31.81 & $14,468.37$ & 454.78 \\
Total & E2 & 24.29 & $18,378.22$ & 756.49 \\
\hline
\end{tabular}


Table 11 Palm per slope analysis.

\begin{tabular}{ll}
\hline Slope class (degree) & No. of palms \\
\hline $0-6$ & 14,329 \\
$7-15$ & 14,930 \\
$16-24$ & 7,173 \\
Total & 36,432 \\
\hline
\end{tabular}

Table 12 Palm per block analysis.

\begin{tabular}{|c|c|c|c|c|c|c|}
\hline Block & Block area & Sub-block & Sub-block area (ha) & Planted area (ha) & Stand count & Palm density (palm/ha) \\
\hline \multirow{2}{*}{ A } & \multirow{2}{*}{59.6} & A1 & 23.12 & 20.61 & 2,541 & 123 \\
\hline & & $\mathrm{A} 2$ & 36.48 & 32.52 & 4,891 & 150 \\
\hline \multirow{2}{*}{$\mathrm{B}$} & \multirow{2}{*}{68.3} & $\mathrm{~B} 1$ & 31.02 & 22.81 & 2,815 & 123 \\
\hline & & B2 & 37.25 & 28.38 & 4,207 & 148 \\
\hline \multirow{2}{*}{$\mathrm{C}$} & \multirow{2}{*}{66.4} & $\mathrm{C} 1$ & 38.25 & 34.30 & 4,389 & 128 \\
\hline & & $\mathrm{C} 2$ & 28.20 & 23.59 & 2,893 & 123 \\
\hline \multirow{2}{*}{$\mathrm{D}$} & \multirow{2}{*}{88.6} & D1 & 48.04 & 37.79 & 4,833 & 128 \\
\hline & & D2 & 40.57 & 28.61 & 3,687 & 129 \\
\hline \multirow{2}{*}{ E } & \multirow{2}{*}{56.1} & E1 & 31.81 & 28.33 & 3,529 & 125 \\
\hline & & E2 & 24.29 & 21.51 & 2,647 & 123 \\
\hline Total & 339.04 & & 339.04 & 278.45 & 36,432 & - \\
\hline Average & & & & & & 131 \\
\hline
\end{tabular}

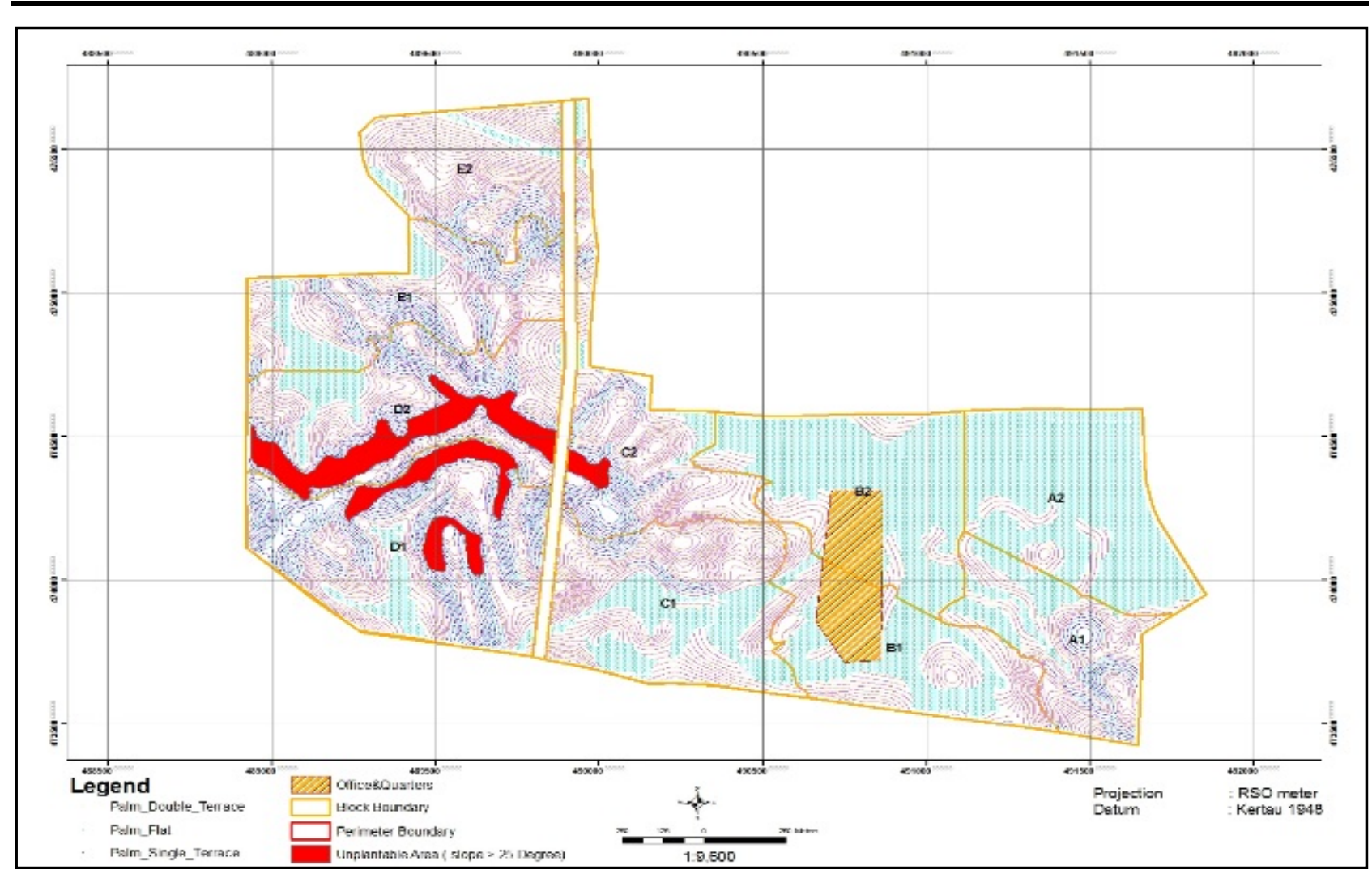

Fig. 13 Estimation of palm per block analysis. 


\section{Conclusion}

It can be concluded that IfSAR technologies are becoming increasingly important in the advancement of the overall spatial information industry associated with mapping, GPS and GIS. Airborne IfSAR mapping is a cost-effective mapping technology due to its many inherent advantages compared with other technologies. It is useful for land evaluation and development for oil palm cultivation. The planters can predetermine block boundaries, road and drainage alignment as well as area to be preserved. With the technologies, the planters could map and determine the road, drainage, terrace length and palm density. This information is useful for the planters in preparing the budget and contract for developing a new oil palm plantation. As the technologies developed and the available of more detail data, planning and developing of plantation using information technologies will be much easier and accurate. The GIS database developed can be used for future management and monitoring of the plantation activities. Under the present stringent requirement with respect to the environment, these technologies could assist the plantation in meeting the certification standards.

\section{Acknowledgements}

The authors express their sincere thanks to the help rendered by the MPOB Geospatial Technology Group, staffs of MPOB Jerantut Station and technical staffs of MySpatial Sdn. Bhd in completing the project successfully. The authors also would like to thank the Director of Biology and Director General of MPOB for their assistance and encouragement through the process of implementing the project.

\section{References}

[1] Abdullah, A. F and Muhadi, N. A. 2015. "GIS Data Collection for Oil Palm (DaCOP) Mobile Application for Smart Phone". ISPRS Annals of the Photogrammetry, Remote Sensing and Spatial Information Sciences, Volume II-2/W2, 2015. Joint International Geoinformation Conference 2015, 28-30 October 2015, Kuala Lumpur, Malaysia.

[2] Adzemi, M. A., Abdullah, M. Z., and Mustika, E. A. 2013. "Spatial Land Evaluation for Oil Palm Cultivation Using GIS (Geographic Information System)." Journal of Environmental Science and Engineering B 2: 177-82.

[3] Internamp Technologies. 2016. IFSAR Product Handbook and Quick Start Guide, Edit Rules Edition v4.5, p. 1-153.

[4] MPOB. 2018. "Oil Palm Planted Area." http://bepi. mpob.gov.my/images/area/2018/Area_summary.pdf.

[5] Nordiana, A. A., Wahid, O., Esnan A. G., Zaki A., Tarmizi, A. M., Zulkifli, H., et al. 2013. "Land Evaluation for Oil Palm Cultivation Using Geospatial Information Technologies." Oil Palm Bulletin 67: 17-29.

[6] Plaut, J. J., Rivard, B., and D’lorio, M. A. 1999. "Radar: Sensors and Case Studies." In Remote Sensing for the Earth Sciences: Manual of Remote Sensing, 3rd ed., edited by A. N. Rencz. New York: Wiley, 613-42.

[7] Richards, M. A. 2007. "A Beginner's Guide to Interferometric SAR Concepts and Signal Processing." IEEE A\&E Systems Magazine 22 (9): 25.

[8] Zebker, H., Werner, C., Rosen, P., and Hensley, S. 1994. "Accuracy of Topographic Maps Derived from ERS-1 Interferometric Radar." IEEE Transactions on Geoscience and Remote Sensing 32: 823-36. 